\title{
Morphological Evidence for Austric
}

\author{
Lawrence A. Reid
}

Oceanic Linguistics, Vol. 33, No. 2. (Dec., 1994), pp. 323-344.

Stable URL:

http://links.jstor.org/sici?sici=0029-8115\%28199412\%2933\%3A2\%3C323\%3AMEFA\%3E2.0.CO\%3B2-Z

Oceanic Linguistics is currently published by University of Hawai'i Press.

Your use of the JSTOR archive indicates your acceptance of JSTOR's Terms and Conditions of Use, available at

http://www.jstor.org/about/terms.html. JSTOR's Terms and Conditions of Use provides, in part, that unless you have obtained prior permission, you may not download an entire issue of a journal or multiple copies of articles, and you may use content in the JSTOR archive only for your personal, non-commercial use.

Please contact the publisher regarding any further use of this work. Publisher contact information may be obtained at http://www.jstor.org/journals/uhp.html.

Each copy of any part of a JSTOR transmission must contain the same copyright notice that appears on the screen or printed page of such transmission.

The JSTOR Archive is a trusted digital repository providing for long-term preservation and access to leading academic journals and scholarly literature from around the world. The Archive is supported by libraries, scholarly societies, publishers, and foundations. It is an initiative of JSTOR, a not-for-profit organization with a mission to help the scholarly community take advantage of advances in technology. For more information regarding JSTOR, please contact support@jstor.org. 


\title{
MORPHOLOGICAL EVIDENCE FOR AUSTRIC ${ }^{1}$
}

\author{
LAWRENCE A. REID \\ SOCIAL SCIENCE RESEARCH INSTITUTE \\ UNIVERSITY OF HAWAI'I AT MĀNOA
}

\begin{abstract}
The morphologies of certain Austroasiatic and Austronesian languages, and of the parent languages reconstructed for these two groups, are compared. Striking similarities of form and function are revealed in derivational affixes (including prefixes, infixes, and suffixes), as well as in particles with syntactic functions and in the pronoun systems. Similarities are also revealed in major syntactic features. Among the Austroasiatic languages, those of the Nicobar Islands appear to be most similar to Austronesian. A number of possible explanations for the facts revealed by this comparison are considered. The question is especially perplexing as to why Nicobarese morphology should appear so similar to Austronesian, while its lexicon resembles neither Austronesian nor to a great extent that reconstructed for its own family. The conclusion is reached that while Nicobarese is indeed a conservative Austroasiatic language, especially in its grammar, the deviance of its vocabulary may be due to a substratum-that the original inhabitants of the Nicobars may have spoken languages that were neither Austroasiatic nor Austronesian.
\end{abstract}

1. INTRODUCTION. The possible relationship of certain Austronesian languages with languages in mainland Southeast Asia was first proposed by Keane in 1880 , and subsequently by Gabelentz in 1881 , who noted certain similarities between Nicobarese and what was then known as the Malayo-Polynesian family. But it was Schmidt who in 1906 made a systematic study of the Austroasiatic family and gave the hypothesis a much firmer basis. It was Schmidt (1906:8182) who first proposed the names Austroasiatic, Austronesian, and Austric. ${ }^{2}$

Writing at the beginning of the century, Schmidt did not have the benefit of the extensive work that has been done in recent years on the reconstruction of the phonology, morphology, and syntax of Proto-Austronesian, and was guilty of making the same kind of premature judgments about the relationship between Austroasiatic and Austronesian languages as he had accused Keane of making: "Keane attempted to demonstrate a link between the Oceanic peoples and languages and a number of those of Indo-China, especially the Khmer, Bahnar, etc., which he attributed to be Caucasian in origin. Quite aside from the rather fantastic character of the latter claim, and a number of similarly

Oceanic Linguistics, Volume 33, no. 2 (December 1994)

(c) by University of Hawaii Press. All rights reserved. 
incorrect details, the core of his hypothesis is correct. The evidence for the hypothesis is, however, not sufficient" (p. 59).

Speaking of the relationship between Austroasiatic and Austronesian languages, Schmidt then made a few "rather fantastic" claims of his own: "I find the proof of this firstly, in the fact that their phonological systems are exactly the same; secondly in the complete agreement of their original morphological systems; thirdly, in a number of important and not so important points of grammar, namely, (a) the postposition of the genitive, (b) the use, and to some extent the form of the possessive, (c) the existence of exclusive and inclusive forms of the first person plural pronoun in a number of these languages; and fourthly, in the extensive agreement of their lexicons" (p. 72).

In this paper I take a closer look at certain areas of the morphology and syntax of the two families in an attempt to demonstrate that even though there is certainly not the "complete agreement" that Schmidt claimed for them, the similarities, especially when Nicobarese is considered, are far stronger than can be attributed to coincidence, or, in the case of the syntax, can be attributed to parallel typological developments. I had considered the possibility of calling this paper "What is an Austroasiatic language doing with Austronesian morphology and syntax?," which would have implied that the observed similarities are probably the result of contact. I take the position though, as I argue at the end of the paper, that this is not the best explanation for the facts. The distribution in the Austroasiatic languages of the features that are apparently shared with Austronesian argues instead for an explanation in terms of inheritance from a common ancestor.

\section{THE POSITION OF NICOBARESE IN AUSTROASIATIC. Austroasiatic} is a widely dispersed family with two major branches, the Munda languages in India, and what is commonly referred to as the Mon-Khmer branch in Southeast Asia. The family spreads from Central and Eastern India in the west to the Nicobar Islands, Burma, Thailand, Laos, southwestern Yunnan province in China, Kampuchea, Malaysia, and Vietnam in the east. There are about twelve different families generally recognized among the non-Munda languages, although the relationships among them are not at all clear (Wurm and Hattori 1981, Ruhlen 1987, Parkin 1991). The population of the whole family is over 60 million, the majority of whom (some 45 million) speak Vietnamese. The next largest group is Khmer with 4-6 million speakers.

Diffloth (1982) groups the Mon-Khmer languages into three major branches, North, East, and South. Of particular interest for the purposes of this paper are the languages of the Nicobar Islands, generally characterized as Nicobarese, which according to Diffloth subgroup with Mon and the Aslian languages in the northern Malay peninsula and southern Thailand to form the South branch of Mon-Khmer. 
The Nicobar Islands are a group of about a dozen inhabited and seven uninhabited islands lying immediately north of Sumatra and south of the Andaman islands to the west of southern Thailand. Toward the end of the last century, Man (1889) estimated that there were about 6,200 speakers of aboriginal languages. They were divided linguistically into six communities. Car, the northernmost island, had about half of the total number of speakers. The other half were divided among the remaining languages. The Nicobarese language group is of great interest because it has been shown to have a number of morphological and syntactic features that are strikingly similar to those found in Austronesian languages.

3. MORPHOLOGY. The aspect of Nicobarese that first stimulated Schmidt and others to note its similarities to Austronesian was not only that the language was typologically similar to languages such as Malay (with which they usually compared it) in having prefixes, infixes, and suffixes attached to verbs, but also that the form and function of these affixes in many respects appeared to be similar to those in many Austronesian languages.

3.1 MORPHEME STRUCTURE. The structure of Nancowry Nicobarese ${ }^{3}$ roots is similar in several respects to that of most Mon-Khmer languages. The majority of roots are monosyllabic, of the shape $\mathrm{CV}(\mathrm{V})(\mathrm{C})$. Any one of the ten vowel phonemes can occur in a root syllable, with nasality and/or length also occurring with certain of the vowels. Disyllabic roots also occur. The form of the initial syllable is always CV. This syllable is always unstressed, and the vowel is invariably either $/ \mathrm{i} /, / \mathrm{a} /$, or $/ \mathrm{u} /$. In addition, in Car Nicobarese (Braine 1970) a fourth vowel /a/ can occur in an initial syllable. Monosyllabic roots can be prefixed with what Radhakrishnan refers to as root prefixes. Most of these are no longer productive and cannot be assigned meaning. Monosyllabic roots may also be reduplicated. The rules of reduplication involve some complex phonological changes, so that the initial reduplicative prefix often appears to have nothing in common with the root, as for example the initial syllables of Ru.ciaw 'to whistle', Rit.các 'to pray' both of which are reduplicative. In many cases, the reduplicative prefix serves only to carry other affixation.

\subsection{AUSTROASIATIC CAUSATIVES *pa-/-ap- AND *ka-. In Austro-} asiatic languages there are two affixes that can be reconstructed with a causative function. They are PAA *pa-, and *ka-. In Nancowry, a reflex of PAA *-um- (elsewhere an agentive nominalizer) also marks causative. Nancowry -um- and $h a_{-}{ }^{4}$ are generally in complementary distribution, with $h a$ - being prefixed to monosyllabic roots, and -um- coming after the first consonant of disyllabic roots, replacing the vowel of the initial syllable. 

cím 'cry'
ha-cím 'to cause someone to cry'
pút 'come out'
ha-pút 'to cause to come out'
té? 'touch'
paló? 'lose'
ha-té? 'to cause to touch'
p.um.ló? 'to cause someone to lose something'

In many cases where the root has a stative meaning, $-u m$ - results in a transitive verb that can also be viewed as a causative.

$\begin{array}{ll}\text { takuác 'scratched' } & \text { t.um.kuác 'to scratch' } \\ \text { lapúh 'supported' } & \text { l.um.púh 'to support' }\end{array}$

In at least some cases, -um- appears to have an inchoative meaning.

lán 'to feel good' t.um.lánhala 'become good' 5

Some roots can have both the $h a$-prefix and the -um-infix attached, although without a double causative meaning, as Radhakrishnan notes.
mih 'rain'
ha-mih, h.um.mih 'to cause to rain'
sul 'fear'
h.um.súl 'to frighten'

He also notes, as other possible counterevidence to his analysis of ha- and $-u m$ - as alternate forms of the same causative element, that only one of the two (only $h a$ - and never -um-) cooccurs with the instrumental.

Other Mon-Khmer languages derive causatives with an initial labial (Schiller 1987). Some, including Katu (Costello 1966:80), retain a full reflex of PAA *pa-.
val 'to return'
pa-val 'to cause to return'
sooq 'to flee'
pa-sooq 'to cause to flee'

Most other Mon-Khmer languages (Pear, Khmu?, Semai, Temiar, Pacoh, Bahnar, for example) reflect PAA *pa- as po-, the vowel of the prefix being centralized under the usual preroot syllable unstressed conditions in these languages. Similarly, Khmer reflects a p-causative (Jenner 1980-81:xxxv).

Other languages (Sre, Thavung, Rengao, Middle Mon, for example) have a voiced labial causative prefix (bo-) that can be shown in several cases to have developed from an unvoiced labial, possibly by assimilation to voiced initial consonants of the root. These Sre examples are from Manley (1942:46).

$$
\begin{array}{ll}
\text { son 'straight' } & \text { bə-son 'to straighten' } \\
\text { sàr 'hard' } & \text { bə-sàr 'to harden' }
\end{array}
$$

In Chrau, $p a$-, va-/-ap- are said to have indeterminate meanings (D. M. Thomas 1969:103, 106; D. D. Thomas 1971:153), although a number of forms appear to stand in a factitive relation. 


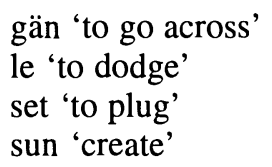

pa-gän, va-gän 'crosswise' pa-le 'roll over (as in bed)' s.ap.et 'a plug, cork' s.ap.un 'fate'

Pinnow (1966) reconstructed Proto-Munda *ab-, *ab- 'causative' on the basis of forms such as those found in Sora. ${ }^{6}$
jum to eat
ab-jum, aj-jum to feed

A number of the Munda languages (such as Sora, Kharia, and Juang) have both an infix $-b$-, as well as a prefix $a b$-. In this case, as in others to follow, the alternation must have been between a prefix *ba- and an infix *-ab- that developed by metathesis of the original root consonant with the initial consonant of the prefix. With loss of the original prefix, the vowel-initial infixed form can become reinterpreted as a vowel-initial prefix, especially where roots begin with a glottal stop. This phonological basis for the development of infixes from prefixes is found not only in Austroasiatic languages, but also in the Austronesian family. Each of the prefixes and infixes to be discussed here has a metathesized counterpart in one or more of the languages of either the Austronesian or Austroasiatic groups. Even in Nancowry, there is a "root prefix" $h a$ - (probably originally a causative) for which, according to Radhakrishnan (1970:48) "there is some evidence to support treating as a variant of $/$-ah- $/$, a nominalizer affix." Furthermore, the tendency to reinterpret the vowel-initial infixed forms as prefixes, as illustrated above for the Munda causative $a b$-, may be demonstrated for other affixes in other languages, Austroasiatic as well as Austronesian.

In addition to the labial causative, a number of Mon-Khmer languages (including Mon, Khmer, and Semai) have reflexes of PAA *ka- 'causative prefix' (Schiller 1987:210). In Katu (Costello 1966:77), both causatives may cooccur.

ku pa-chet anuq

ku ka-chet anuq

ku pa-ka-chet mei anuq
'I cause dog die'

'I cause dog die'

'I cause you to cause the dog to die'

In Nancowry, Radhakrishnan (1970:46) describes a $\mathrm{ka}$ - "root prefix" that in a number of cases appears to have a stative causative meaning.
?ẽc 'tight'
yé? 'be afraid'
ka-Rẽc 'be strangled'
yón 'to drip'
ka-yé? 'wild'
ka-yón 'to shake out grains'

\subsection{AUSTRONESIAN CAUSATIVES *pa-, *ka-, AND *paka-. In Austro-} nesian, it is necessary to reconstruct three causative forms, PAn *pa-, *ka-, and *paka-. PAn *pa- has been widely discussed. Its reflexes are found throughout the family, as for example in Bontok. 


$\begin{array}{ll}\text { Pinúm 'drink' } & \text { pa-Pinúm 'cause to drink' } \\ \text { kán 'eat' } & \text { pa-kán 'feed' } \\ \text { téy 'die' } & \text { pa-téy 'kill' }\end{array}$

Reflexes of PAn *ka- 'causative' also occur alongside $p a$ - in many languages. In Bontok, the form derives a stative causative verb from nouns. The derivation also requires a $\mathrm{CV}$ - reduplication.
sunet 'anger'
?iyek 'laughter'
sunet 'anger'
Riyek 'laughter'
pa-suyet 'to make angry' pa-Riyek 'to make laugh' ka-susunet 'that which causes anger, having the ability to produce anger' ka-kaRiyek 'funny, having the ability to produce laughter, laughable'

The prefix $k a$ - similarly occurs as a causative in Soboyo (a language in the Moluccas) as well as in a number of Nuclear Micronesian languages.

That both affixes could cooccur in Proto-Austronesian as *paka- 'causative' is suggested by reflexes in Formosan, Philippine, and Oceanic languages. In Tsou, the reflex is po?a 'causative'. ' In Uma Juman Kayan, a Bornean language, it is pak- (Blust 1977). In Amis, as in several Philippine languages such as Maranao (McKaughan 1958:34), the reflex is paka- and derives abilitative as well as causative verbs.

$$
\begin{aligned}
& \text { tabas 'cut' paka-tabasen 'to cause so to cut st., } \\
& \text { to be able to cut st.' }
\end{aligned}
$$

\subsection{THE AUSTROASIATIC AGENTIVES *-um- AND *ma-/-am-. Con-} sidering only data from mainland Mon-Khmer languages, it is not possible to reconstruct a specific vowel for Proto-Austroasiatic infixes, because the presyllable vowel color in these languages typically depends on the consonant of the root. Both *-um- and *-am- are reflected as the same affix $-(V) m$-. However, considering the Nicobarese forms, it is possible to reconstruct separate PAA affixes, ${ }^{*}$-um- as well as *-am-. In Nancowry, the two forms usually have different functions, causative versus agentive, and in addition -am-alternates with $m a$ - The latter is prefixed to reduplicated roots, or to roots carrying the $h a$-causative prefix. The infix - am- occurs with other roots. On reduplicated roots (the first consonant of which is always glottal stop), the agentive prefix replaces the initial glottal stop, and is itself reduced to $m$-. Its function includes the deriving of both agentive nominalizations (cim 'to cry', hacim 'to cause to cry', mahacim 'one who causes someone to cry'; Ritkéc 'to pluck', mitkéc 'one who plucks') and patient nominalizations (kuán 'strong', kamuán 'strong person'; Pup?áp 'to be closed', mup?ap 'one that is closed'). 
Radhakrishnan claims that in roots that have an initial high back vowel, the infix appears as -um- (pumón 'to fight', pumumón 'fighter, army'), so that at least in this position there may be neutralization between the two infixes. However, it should be noted that even in this position there are examples in Radhakrishnan's data in which -am-, not -um-, appears (kamuáy 'strong person').

In Khmer, a number of forms appear to contain a reflex of *-am- 'agentival derivative' (Jenner 1969:144-147, 1980-81:xlvii).

$\begin{array}{ll}\text { phək 'to drink' } & \text { p.m.ək 'one who drinks' } \\ \text { luəc 'to steal' } & \text { l.m.uəc 'thief, robber' } \\ \text { rut 'to run away' } & \text { r.m.ut 'fugitive' }\end{array}$

In Pear am- is described by Headley (1977:79) as being "probably causative."

snik 'light' am-snik 'lighten'

kring 'thin (?)' am-kring 'to make thinner'

3.5 THE AUSTRONESIAN AGENTIVES *mu-/-um- AND *maRa-. In Austronesian languages, -um- appears widely as a verbal affix. It alternates (sometimes in the same language) with a prefix $m u$ - (Cebuano, Tsou). The alternation developed in the same way as was noted above for the Austroasiatic causatives $p a$ - and - $a p$-, that is, by metathesis of the first two consonants of the prefixed root. The infix sometimes also occurs as a prefix um(Inibaloi, Alta). In the latter two languages, the switch from infix to prefix apparently resulted from the loss of glottal stop at the beginning of otherwise vowel-initial words.

Starosta, Pawley, and Reid (1981:123) state that "the original function of *mu-/-um- in Proto-Austronesian was probably that of deriving agentive nominalizations from nouns or verbs, a function very similar to that of -er in English." They also discuss the possible relation between *mu-/-um- and *pain Proto-Austronesian. "Reflexes of *mu-/-um- frequently appear in a paradigmatic alternation with *pa-, suggesting that they may have had similar functions in Proto-Austronesian with *mu- meaning 'doer' and *pa- meaning 'causer'” (1981:126). This affix developed in Western Austronesian languages (and was possibly already in Proto-Austronesian) a means of deriving intransitive (antipassive) verbs. When attached to adjectival or stative verbal bases, it generally derives verbs with an inchoative meaning, as in Bontok.

$\begin{array}{ll}\text { Pákew 'steal' } & \text { P.um.aPákew 'thief' } \\ \text { Pinum 'drink' } & \text { P.um.inum 'to drink; one who drinks' } \\ \text { gawis 'good' } & \text { g.um.awis 'to become good' }\end{array}$


The development of -um- as a causative that was seen in Nancowry is also noted in some Austronesian languages such as Bontok, in which -um- derives causative verbs from some nouns.

sakit 'sickness' $\quad$ s.um.akit 'to cause sickness'

In Proto-Austronesian, *ma- derived patient nominals as well as stative verbs. Various Formosan and Philippine languages provide evidence for its patient nominal function in PAn.

\begin{tabular}{|c|c|}
\hline Rukai (Li 1973, 1975:44) & \\
\hline ma-roDang & 'old man' \\
\hline ma-tama & 'father and son' \\
\hline ina ma-?ilay & 'the cripple' \\
\hline iDa ma- $\theta$ asil & 'the good (person)' \\
\hline iDa ma-DaDawnga & 'the biggest' \\
\hline Bunun (Jeng 1971) & \\
\hline sia ma-kavai & 'the bully' \\
\hline me-bunun & 'human beings' \\
\hline ma-kavas & 'headhunting' \\
\hline ma-dadaingaD & 'old men' \\
\hline ma-sinauba & 'younger brother' \\
\hline ma-situqasun & 'older brother' \\
\hline ma-dikla'an & 'precipice’ \\
\hline Ilokano & \\
\hline ma-bisin & 'hungry person' \\
\hline ma-sakit & 'a sick person \\
\hline ma-turug & 'one who is sleeping' \\
\hline
\end{tabular}

In addition, by affixing to verbs that were first derived with the *Ra- 'distributive, plural' prefix, the 'compound' prefix *maRa- (subsequently *maR-) developed first to derive agent nominals, and then to derive intransitive antipassive verbs. Although reflexes of *Ra- occurring as a verbal (or to my knowledge, nominal) prefix are no longer found in Austronesian languages, reflexes of its infixal counterpart *-aR- 'distributive, plural' are found in many languages.

3.6 AUSTROASIATIC INSTRUMENTAL *-an-, *-in-. Nicobarese has a noun-deriving infix -an-, which typically refers to the instrument used to perform the action of the root. This infix occurs only on monosyllabic roots.
sák 'to spear'
Tihî ${ }^{8}$ 'clear a field'
s.an.ák 'a spear'
h.an.í 'implement used for clearing fields'

On disyllabic roots or roots with a $h a-$ 'causative' prefix, the form of the affix is -in-. This form always replaces the vowel of the syllable in which it occurs. 
hacús 'to encourage' hahét 'to make holes' h.in.cús 'words of encouragement'

h.in.hét 'strainer'

It should be noted that, at least for some of these examples (such as the last one), the derived noun seems to refer not to an instrument for performing the action of the root, but to the object that is the result of the action. To my knowledge there is no equivalent (instrumental) prefixal form $n a$-, or $n i$ - in Nicobarese (or other Austroasiatic languages).

In other Mon-Khmer languages, there is an $-n$ - affix, with a nominalizing function, the source of which could be either *-in- or *-an-. It occurs in several languages in combination with $-m$ - 'causative' as $-m n$-.

\subsection{EXTRA-FORMOSAN INSTRUMENTAL *paN-; AUSTRONESIAN}

*ni-/-in-. Proto-Extra-Formosan (the parent language of all non-Formosan Austronesian languages) had an instrumental prefix ${ }^{*} \mathrm{paN}^{-}{ }^{9}$ that may well have had a complex origin, being a combination of *pa- 'causative' plus *-an- 'instrumental', signifying 'that which is used for causing or bringing about the action of the root'. Reflexes of *paN- occur throughout the family, as in Tagalog (Schachter and Otanes 1972).

$\begin{array}{ll}\text { pam-punas } & \text { 'for use in wiping' } \\ \text { pan-takip } & \text { 'for use in covering' } \\ \text { pay-kuha } & \text { 'for use in getting' }\end{array}$

There are no clear cognates of this form in Formosan languages, although Amis mami- 'instrument affixation on verbs' could possibly be analyzed as $m$ paN-pi-. Chen (1987:81), however, rejects this analysis because she finds no synchronic evidence for a morphophonemic rule $* \mathrm{~N}-\mathrm{p}>m$, even though there is clear evidence of *m-p $>m$.

Austronesian -in- (prefixal counterpart $n i$-) was also primarily a nounderiving affix (Starosta, Pawley, and Reid 1981:85ff.), although it probably did not have an instrumental function. Rather, it referred to the result of the action of the verb, or the thing affected by the action of the verb.

Atayal "-in-/-n- an infix forming nouns" (Egerod 1980)
qaniq 'to eat'
q.n.aniq 'food'
phau 'to fine'
p.n.hau 'a fine'

Paiwan "-in- object or product of past action" (Ferrell 1982)
kan 'eat'
k.in.an 'already eaten food'
alap 'take'
in.alap 'object which has been taken'

Saisiyat

karat 'write' $\quad$ k.in.arat 'book, paper' 
Ilokano

dejden 'cook a d.in.enden 'a cooked vegetable dish' vegetable dish'

Subsequently, with the development of the tense-aspect system in Austronesian, it became the marker of completed action.

\section{Tagalog \\ gawa 'make' \\ lutò 'cook'}

g.in.awa 'made; that which was made' ni-lutò 'cooked; that which was cooked'

Details of the development of *ni-/-in- in Austronesian languages are found in Starosta, Pawley, and Reid (1981).

Another interesting point of similarity between Austronesian and Austroasiatic languages involves the Mon-Khmer sequence -mn-. In Austronesian languages the completed-aspect form of the active verbal infix -um-is -umin-, or in some languages -inum-. It is the former sequence however, that must be reconstructed for Proto-Austronesian (Reid 1992). In Proto-Austronesian the combination would have referred to 'the actor who brought about that which was the result of the action of the verb'.

3.8 AUSTROASIATIC OBJECTIVE *-a. Radhakrishnan (1970:63-64) states that the Nancowry suffix - $a$ refers to "the object or goal which suffers the action indicated in the word."
wí? 'to make'
wí?-a 'a thing made'
ñíh 'sell'
ñíh-a 'things for sale'
haláw 'to buy'
haláw-a 'things bought'

Mon-Khmer languages other than Nicobarese no longer have suffixation of any sort. Munda languages are suffixing, but do not have an - $a$ suffix that could be related to the Nicobarese form.

3.9 AUSTRONESIAN OBJECTIVE *-a. Proto-Austronesian *-a was one of two suffixes (the other being $*_{-i}$ ) that derived transitive verbs in dependent constructions, conditionals, and imperatives. ${ }^{10}$

Tsou - $a$ direct passive

$\begin{array}{ll}\text { mosi 'to put (active)' } & \text { si-a 'to be put' } \\ \text { uso 'to go' } & \text { us-a 'be gone to' } \\ \text { mimo 'to drink' } & \text { im-a 'be drunk' }\end{array}$

Bunun - $a$ goal focus imperative qanup 'hunt' 
Cebuano (Wolff 1972)

ká?un 'to eat'
palit 'to buy'

\author{
ká?n-a 'eat it' \\ palit-a 'buy it' \\ ayaw palit-a 'don't buy it' \\ didtu níya palit-a 'he bought it there'
}

\title{
4. SYNTAX
}

4.1 WORD ORDER. Typologically, Nicobarese is unlike other Austroasiatic languages in being a verb-initial language. It has been generally characterized as SVO (Schmidt 1906), although numerous examples in Radhakrishnan, such as (1) below, show VOS. Other Mon-Khmer languages are typically SVO, while Munda languages, under the influence of non-Austroasiatic languages with which they are in close geographical proximity, are SOV. ${ }^{11}$

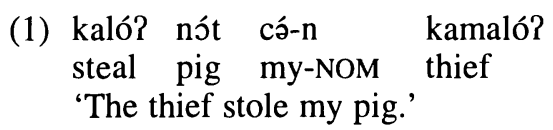

4.2 LIGATURES. Nicobarese, like other Mon-Khmer languages, generally has a Head-Attribute word order, in which adjectives, relative clauses, and other modifiers usually follow their head noun, and objects, complement clauses, and other such constructions usually follow the verb to which they are attributive. In accordance with the universal tendencies of such a word order, these languages also have prepositions rather than postpositions. In Nicobarese, modifiers of both nouns and verbs are usually preceded by a preposition. In Car, the form is a clitic $\partial$. In Nancowry, it is usually na. Since these forms appear to correspond with what have frequently been termed "ligatures" in the literature on Austronesian languages, I label them in the same way here. ${ }^{12}$

Nancowry

(2) ใá na karú?

3s LIG big

'big person (person who is big)'

(3) Pám na Puhú

dog LIG barking

'barking dog (dog that is barking)'

In Nancowry, forms such as hawáltari 'then' and liát 'finish' can function as intransitive verbs, and are followed immediately by their subject noun phrases. Complement clauses introduced by na follow the subject, as in (4) and (5). Similarly, conditionals such as yo? 'if' are verbs and appear in the same position in sentences as other verbs. 
(4) hawáltari ?ufé na rián

then they LIG run

'Then they run.'

(5) liát ?ufé na rián

finish they LIG run

'They finish running.'

(6) ló na Puysón

fast LIG walk

'walk fast'

(7) yo? ?ufé na kóhnarít...

if they LIG fall.backwards

'If they fall backwards...'

Car Nicobarese (Braine 1970:126)

(8) ?ám-ə tú:? əm meh?ع

how.many-LIG sinker you yourself

'How many sinkers do you have?'

(9) ne:t-a lí:pare cin

two-LIG book I

'I have two books.'

(10) lu:y-ə kahé:? man tə có:n

three-LIG thing.taken you of plant

'Take three books.'

(11) larák-ə kanú:c cin

be.split-LIG pencil I

'I have a split pencil.'

Identical forms with similar functions are found in other Austroasiatic languages. Starosta (1967:225) discusses an - $a$ - 'attributive linking element' in Sora. In Khasi, Rabel (1961:104) describes a na 'interfix, occurring between reduplicated adjectives; intensification', as in hak 'forcibly', hak-na-hak 'without cause, uselessly'. In Philippine languages, identical constructions occur.

Proto-Austronesian was typologically very similar to present-day Nicobarese. It was also a verb-initial language, with the subject occurring at the end of the sentence. Headwords preceded their modifiers. This in itself tells us nothing about a genetic relationship (however, see Egerod 1981). But the striking thing is that a ligature with the same forms and functions as are found for the elements we have termed ligatures in Nicobarese must also be reconstructed for Proto-Austronesian. The forms were $*_{n} a$ following words ending in a vowel, and $* a$ following words ending in a consonant.

In many Austronesian languages, one shape or the other has been generalized to occur in all environments. A variety of innovations have also occurred, 
both in the forms of the ligature and their environments, and in the kinds of constructions that require them. In Tagalog, the ligature still has functions similar to those reconstructed for Proto-Austronesian, and to those found in Nicobarese. There are two forms, $n a$ and $-\eta$, with the former currently having the widest distribution. It occurs following words ending in a consonant, and may also occur after any word followed by a pause. The form $-\eta$ attaches to words ending in a vowel (or in $-n)$.

(12) anak na mayaman

child LIG rich

'rich child (child that is rich)'

(13) payat na payat

thin LIG thin

'very thin'

(14) libro- $n$ nasa mesa

book-LIG on.the table

'book that is on the table'

(15) mabilis na lumakad

fast LIG walk

'walk fast'

(16) gusto ni Bob na lutuin ni Maria an pagkain want GEN Bob LIG cook GEN Maria NOM food 'Bob wants Maria to cook the food.'

(17) sumigaw si Manuel na para- $n$ lukuluko shouted NOM Manuel LIG like-LIG crazy 'Manuel shouted like a madman.'

Ilokano reflects the ligature as $a$ in most environments.

(18) taray a taray

run LIG run

'running and running'

4.3 NOUN PHRASE MARKERS. Nancowry and Car differ from many other Mon-Khmer languages in having case-marked noun phrases. In these languages, Nominative noun phrases are preceded by one of a limited number of markers, possibly Determiners. In Nancowry, the form that introduces Nominative (NOM) noun phrases is Pin, as in (19), sometimes reduced to the clitic $-n$ on the word preceding the marker, if that word ends in a vowel (20-21). Locative (LOC) noun phrases are introduced by $t a$ (22-23), and noun phrases that mark the Means (MNS) case relation (as for example the "by" phrase of passive sentences) are introduced by tay (24). 
(19) puáh caltãc ?in pãc eat.meat frog NOM snake 'The snake eats frog.'

(20) nína-n kuán cõ this-NOM son 1s 'This is my son.'

(21) kaló? not cã-n kamaló? steal pig my-NOM thief 'The thief stole my pig.'

(22) yuáya héw cõ ta Rám past see $1 \mathrm{~s}$ LOC dog 'I saw the dog. (I looked at the dog.)'

(23) Puksák ta Puál riák stand LOC in water '(Someone) is standing in the water.'

(24) ciáw-a Pinmé tay Pán call-OBJ 2s MNS 3s 'You are called by him/her.'

Other Mon-Khmer languages, such as Old Khmer (Jacob 1991) and Khmu (Premsrirat 1991:124-125), also mark locative phrases with a ta preposition.

Khmu

(25) ja? jat ta ka:y grandmother stay at home 'My grandmother is at home.'

(26) ?o? pé płən jo ta jú? I not able go to forest 'I didn't have a chance to go to the forest.'

In Old Khmer $t a$ also marked direct objects. In Mal (a Tin language), the form appears as a noun meaning 'place' in combinations such as taa-nee 'here' and taa-een 'there', and as a relative clause marker (Filbeck 1991).

In Car, Nominative phrases are introduced by one of a set of markers, including ?an, ?an, and nun (27-29). Locative phrases are marked by either ?i or Pin. The marker Pin occurs with proper animate nouns, pronouns, and reflexives: Pín co:n 'to John', Pín o 'with him', Pinre 'to oneself'. The marker ?i occurs elsewhere (30-32).

Car Nicobarese (Braine 1970:124-129)

(27) la?óh ?ən yih kalré:n cu broken NOM this leg my 'My leg is broken.' 
(28) tacíta ?an yoh kanuò:c goh short NOM this pen this 'This pen is short.'

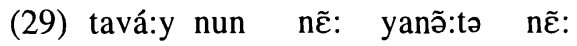
pretty NOM these jewel these 'These jewels are pretty.'

(30) i ró:y có:n

LOC branch tree

'in the tree'

(31) i kú:y rónə

LOC top hill

'on top of the hill'

(32) i kuyá:yə

LOC seashore

'by the seashore'

In Proto-Austronesian, Nominative noun phrases may have been unmarked for case. There was, however, a Locative case marker $* \mathrm{i}$, which is still reflected in many of the daughter languages. In Proto-Philippines this form became the marker for Nominative noun phrases. It was often immediately followed by a demonstrative, which became fused with the case marker, thus Ilokano $i$ - $t i$ 'locative determiner', Tagalog $i$ - $t u$ 'this (Nom)', and so forth. One of the demonstratives that could occur in this position was na (the same form that developed as a ligature in Proto-Austronesian), as for example Bikol $i$-na 'that (Nom)'. Now, it is not at all uncommon for demonstratives that have become fused with a preceding particle to lose their final vowel, so that in some of the Central Philippine languages *i-ti became $i t$, and in Kagayanen Manobo, *a-na (originally LIG-'that') developed into a definite article -an, postclitic to nouns. It is possible that the Nancowry Nominative marker Pin, and the Car marker ?an developed in the same way: *?i-na > Nancowry Pin, and *?a na > Car ?an. Similarly, the Car locative personal noun marker Pin may have developed from a sequence of $*$ ?i-ni, where $n i$ was a personal noun marker.

In Formosan languages, a reflex of PAn *ta 'locative preposition, demonstrative' occurs as a derivational prefix, deriving location and time nouns in Rukai (Li 1973:272). In Tsou (Tsuchida 1976:94) ta occurs as a distant Nominative marker and a general non-Nominative marker of goal, location, and agent noun phrases. In the Philippines, *ta must be reconstructed as a locative preposition for the parent of the Northern Cordilleran languages, and it has widespread use as a demonstrative, as in Ilokano ta aso 'that (near hearer) 
dog'. Furthermore, $t a$ functions in many Austronesian languages as a conjunction introducing purpose clauses, as in Bontok.

\begin{tabular}{|c|c|c|c|c|c|}
\hline $\begin{array}{l}\text { (33) iyali-m } \\
\text { bring-2s }\end{array}$ & $\begin{array}{l}\text { nan } \\
\text { NOM }\end{array}$ & $\begin{array}{l}\text { sa-na } \\
\text { that-LIG }\end{array}$ & $\begin{array}{l}\text { mangga } \\
\text { mango }\end{array}$ & $\begin{array}{l}\text { ta } \\
\text { so.that }\end{array}$ & $\begin{array}{l}\text { kan-e-k } \\
\text { eat-OBJ-3s }\end{array}$ \\
\hline
\end{tabular}

To my knowledge, Austronesian languages do not use tay as a marker of the Means case relation in passive clauses, but the form does appear in many Northern Philippine languages introducing causative clauses, a function that is probably relatable to its Means function in Nicobarese. The next example is also from Bontok.

(34) iyali-m nan sa-na mangga tay layd-e-k
bring-2s NOM that-LIG mango because like-OBJ-3s
'Bring me that mango because I want it.'

4.4 PRONOUNS. Various other syntactic features of a typological nature found in Nicobarese are similar to those found in Austronesian languages. There is a distinction in Nancowry (and probably also in Car), as in Austronesian languages, between "short-form" and "full-form" pronouns. The shortform pronouns consist only of a pronominal root such as cã 'I, my'. They appear enclitic to nouns as possessive pronouns (35), and enclitic to verbs as nominative pronouns in some constructions (36). In Proto-Austronesian, genitive clitic pronouns were attached to nouns as possessive pronouns. With the reinterpretation of certain nominal forms as verbs (discussed in Starosta, Pawley, and Reid 1981), the genitive pronouns that were enclitic to them were interpreted as agentive pronouns.

Full-form pronouns in Nicobarese consist of in plus a pronominal root, such as Pincá 'I, my' (38-39). Although it appears that these forms were originally case-marked nominative pronouns, they are probably no longer synchronically analyzable as such, because two pronouns of the same type may occur together in the same clause, only one of which may be the subject (40). Also, the full form of the pronoun is the base to which the marker $t a$ (or $t$-) is prefixed to form locative pronouns, such as t-in?án 'to, at him' (36-37).

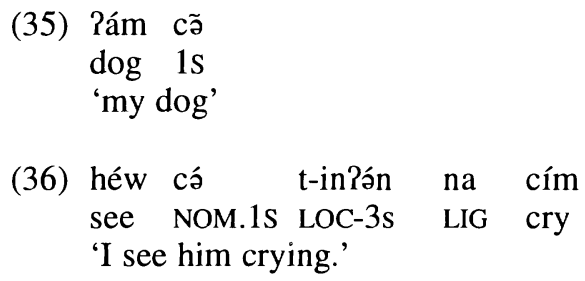


(37)

ciáw t-in?án inmé

call LOC-3s NOM.2s

'You call to him (to come).'

(38) yó? rúk ?incã

want come NOM.1s

'I want to come.'

(39) rián Pincã

run NOM.1s

'I am running.'

(40) ciáw in?án inmé

call ACC.3S NOM.2S

'You call him (his name).'

4.5 ERGATIVITY. Proto-Austronesian was probably an ergative language in that its normal (unmarked) choice for subject in both transitive and intransitive clauses was the noun phrase that carried the patient case relation. Although Nancowry is probably an accusative language now in that its unmarked choice for subject (like English) in transitive clauses appears to be the noun phrase that is the actor rather than the patient, there are clues that at some point in its history it was ergative. Such clues include the use of what appear to be genitive pronouns for the agent of what could have been at some stage a transitive clause. Compare (36) with (39), which is clearly intransitive, and which still retains a long (previously nominative-marked pronoun). Similarly, sentences that are syntactically as well as semantically transitive (in that they have personal pronoun objects) and would have originally required the "object" to be nominatively marked, still use pronouns carrying the Pin marker, as in (40-42). ${ }^{13}$

$$
\begin{aligned}
& \text { (41) yú?-si in?án ta-yáné } \\
& \text { put-down ACC.3s LOC-that } \\
& \text { 'Put him (or her) farther away there.' } \\
& \text { (42) sám-ya in?án t-inẽh } \\
& \text { send-away ACC.3s LOC-this.here. } \\
& \text { 'Send him (or her) (who is not near).' }
\end{aligned}
$$

5. CONCLUSION. The similarities between the morphology and syntax of Nicobarese and Austronesian languages discussed in the above sections seem to me to be more than the result of chance, or the result of simple typological parallel developments in two genetically unrelated language families. Various other possible explanations for this state of affairs exist.

It is possible to argue that since Nicobarese seems quite clearly to be an Austroasiatic language in terms of its lexicon, perhaps it borrowed its morphology through contact with some Austronesian language. This is an explanation 
that, given the geographical location of the Nicobar Islands lying off the northwest tip of Sumatra, sounds like it might have some merit. There are two problems with it, however. First, although nothing is really immune from being borrowed between languages, it is highly unlikely that a whole system of verbal morphology, including prefixes, infixes, and suffixes would be borrowed, without the word roots that carried that morphology in the donor language also being borrowed. The second problem with this explanation is that some of the verbal morphology that is supposedly of Austronesian origin is also found in other Austroasiatic languages, including Munda languages, which are extremely distant from any known Austronesian influence.

Another possible explanation, given its geographical location, is that Nicobarese may really be an Austronesian language that through contact with some Austroasiatic language was subsequently relexified. The problem with this explanation is that if this were to have happened, the language would have had to have been spoken somewhere on the mainland, where the contact could have been long enough for relexification to have taken place. Moreover, we would probably be able to determine what the source language was. Also, if this were to have happened, we would need to explain why Nicobarese did not acquire other characteristic features of Mon-Khmer languages, such as their typical SVO word order, as occurred with the Chamic languages. (Nicobarese is generally VOS.) And we would still have the problem of explaining the distribution of an "Austronesian" morphology in other Austroasiatic languages.

The other possible explanation is that Nicobarese is a very conservative language, reflecting much of what must be reconstructed for the morphology and syntax of Proto-Austroasiatic. This seems to be the most reasonable explanation. That Nicobarese really is Austroasiatic has been firmly established, although the percentage of shared vocabulary that it maintains with other Austroasiatic languages is lower than perhaps for any other language within the family. Its geographical location, far off the coast of mainland Southeast Asia, is what accounts for its differences from other Austroasiatic languages in morphology and syntax. It has not been subjected to the great leveling influences of Thai (and ultimately Chinese). These influences have resulted in a set of areal features that characterize the mainland Austroasiatic languages, but not Nicobarese. Nicobarese is a classic example of a conservative "relic" language.

Although it does not seem reasonable to believe that Nicobarese is an Austronesian language that has been relexified by contact with an Austroasiatic language, it is possible that some relexification from some non-Austroasiatic source has occurred, thereby bringing about the the low cognate percentages that Nicobarese has with other Austroasiatic languages. The earliest inhabitants of these islands were probably not these Austroasiatic speakers from the mainland at all. Given the distribution of early Negrito populations in the Andamans just to the north of the Nicobars, on the Malay Peninsula to the East, and in other island areas of Southeast Asia, it is quite possible that the 
Nicobars were originally inhabited by Negritos whose language contributed much of the non-Austroasiatic lexical component to Nicobarese, before being completely assimilated into the Austroasiatic population.

\section{NOTES}

1. An earlier version of this paper, "The Nicobarese evidence for Austric," was read at the symposium: The Austronesians in History: Common Origins and Diverse Transformations, Australian National University, Canberra, November, 1990; and later presented as "Another look at the Austric hypothesis" to the Austronesian Circle, Honolulu, March, 1991. I wish to thank Andrew Pawley, Robert Blust, George Grace, and Stanley Starosta for their comments on one or the other of the earlier versions. Their willingness to comment, of course, did not imply their agreement with the conclusions that I draw from the data. I alone am guilty of that.

Abbreviations used in this paper include PAn, Proto-Austronesian, and PAA, Proto-Austroasiatic.

2. Says Schmidt, "Instead of the name 'Malayo-Polynesian', which threatens to be incorrect for anthropological reasons as well, some time ago I suggested the name 'Austronesian'. This was for linguistic reasons, since, as recent research has shown, 'Polynesian' does not have the same rank as 'Malay', being rather a descendant, having a grandchild's relationship to Malay, so that 'Malayo-Polynesian' is as if one said 'Indo-Bavarian' instead of 'Indo-European' or 'Indo-Germanic'. I recommended the designation 'Austronesian' because the names of the individual areas within the whole region have been formed in a similar way: 'Indonesian', 'Melanesian (Micronesian)', and 'Polynesian', and these are practically all island languages. Furthermore, all of the island world lies in 'Auster', in the seas south of Asia, from which another bit of terra firma got its name as well, 'Terra Australi'. Building on the name 'Austronesian', I would now like to give the name 'Austroasiatic' to all of the languages of Further India and Indo-China, whose relationship to one another we have proven. I have chosen this name because they take in parts of south east Asia, and at least in comparison with the Tibeto-Burman languages, represent the earlier, and perhaps only aboriginal occupants of this region. From these two names, 'Austronesian' and 'Austroasiatic', I would now like to hereby present this newly established, large family with the name 'The Austric Language Family'." This and subsequent citations from Schmidt were translated by Craig Volker, who recently completed his doctorate at the University of Hawai 'i.

3. The Nancowry data cited in this and following sections are all from Radhakrishnan (1970), a Ph.D. dissertation on the language of the inhabitants of Nancowry Island in the Nicobars.

4. Schmidt claims that Nicobarese $h a-$ is a reflex of an earlier ${ }^{*}$ pa- $>*$ fa-.

5. The derivational suffix -hala is unexplained.

6. Pinnow (1966:116) also reconsructed Proto-Munda *-Vp- 'reciprocal', but noted that, "In Proto-Munda, the infix may have had a function other than the formation of reciprocal verbs."

7. Wolff (1973:81) states, "In Ts *pa- is reflected only in remnants, but a prefix po?a(from earlier paka-, probably a reformation of this prefix pa-) carries out the same function as the reflexes of pa- in other Austronesian languages." 
8. The $2 i$ - on this form is a reduplicative prefix.

9. The uppercase $\mathrm{N}$ is used for a nasal that assimilates to the point of articulation of the first root consonant. The base form could have been either *pan- or *pay-.

10. PAn *-a "functioned to derive transitive verbs from intransitive by adding an Agent to the case frame" (Starosta, Pawley, and Reid 1982:154); "direct passive dependent" (Wolff 1973:87).

11. There is evidence, however, that Proto-Munda was also a verb-initial language.

12. Braine calls $a$ an "attributive." Radhakrishnan calls na a "particle." The analysis of this marker as a preposition in both Nancowry and Car is mine.

13. Dr. Elangaiyan, an Indian scholar who recently completed a grammar of Car Nicobarese, remarked to me that the language seemed to use "passive constructions" far more frequently than one might expect. Perhaps Car is still an ergative language.

\section{REFERENCES}

Blust, Robert, 1977. Sketches in the morphology and phonology of Bornean languages 1: Uma Juman (Kayan). Papers in Bornean and Western Austronesian Languages, no. 2. Pacific Linguistics A33:7-122.

Braine, Jean Critchfield. 1970. Nicobarese grammar (Car dialect). Ph.D. dissertation, University of California, Berkeley. University Microfilms 71-15,730.

Chen, Teresa M. 1987. Verbal constructions and verbal classification in Nataoran-Amis. Pacific Linguistics C-85. Canberra: Australian National University.

Cohen, Patrick. 1976. The noun phrase in Jeh. Mon-Khmer Studies 5:139-152. Manila: The Summer Institute of Linguistics.

Costello, Nancy. 1966. Affixes in Katu. Mon-Khmer Studies 2:63-86. Saigon: The Linguistic Circle of Saigon and the Summer Institute of Linguistics.

Diffloth, Gérard. 1977. Mon-Khmer initial palatals and substratumized Austro-Thai. Mon-Khmer Studies 6:40-47. Honolulu: The University Press of Hawaii.

- 1982. On the Palaungic branch of Mon-Khmer. Paper presented to the 15 th International Conference on Sino-Tibetan Languages and Linguistics, Peking.

Egerod, Søren. 1980. Atayal-English dictionary. Monograph no. 35. London: Scandinavian Institute of Asian Studies.

- 1981 . To what extent can genetic-comparative classifications be based on typological considerations? In Typology and genetics of language, pp. 115-155. Travaux du linguistique de Copenhague XX.

Ferrell, Raleigh. 1982. Paiwan dictionary. Pacific Linguistics Series C-73. Canberra: Australian National University.

Filbeck, David. 1991. Information processing in Mal discourse. In Austroasiatic languages: Essays in honor of $H$. L. Shorto, ed. by J. H. C. S. Davidson, pp. 161182. London: School of Oriental and African Studies, University of London.

Gabelentz, Georg von der. 1881. Sur la possibilité de prouver l'existence d'une affinité généalogique entre les langues dites indochinoises. In Proceedings of the International Congress of Orientalists 4 (Florence), pp. 283-293.

Gradin, Dwight. 1976. Word affixation in Jeh. Mon-Khmer Studies 5:25-42. Manila: The Summer Institute of Linguistics.

- 1976. The verb in Jeh. Mon-Khmer Studies 5:43-75. Manila: The Summer Institute of Linguistics. 
Gregerson, Kenneth. 1979. Predicate and argument in Rengao grammar. S.I.L Publications in Linguistics no. 69. Dallas: The Summer Institute of Linguistics and The University of Texas.

Haudricourt, André G. 1954. De l'origine des tons viêtnamien. Journal Asiatique 242:69-82.

Hayes, La Vaughn H. 1982. The mutation of $* \mathrm{R}$ in Pre-Thavung. Mon-Khmer Studies 11:83-100. Honolulu: University of Hawaii Press.

Headley, Robert K. 1977. A Pearic vocabulary. Mon-Khmer Studies 6:78-115. Honolulu: The University Press of Hawaii.

Jacob, Judith M. 1977. Sanskrit loanwords in Pre-Angkor Khmer. Mon-Khmer Studies 6:166-167. Honolulu: The University Press of Hawaii.

-1991. A diachronic survey of some Khmer particles (7th to 17 th centuries). In Austroasiatic languages: Essays in honor of $H$. L. Shorto, ed. by J. H. C. S. Davidson, pp. 193-225. London: School of Oriental and African Studies, University of London.

Jeng, Heng-hsiung. 1971. A Bunun-English dictionary. Mimeo. Taipei.

Jenner, Philip N. 1980-81. A lexicon of Khmer morphology. Mon-Khmer Studies 910. Honolulu: The University Press of Hawaii. 524 pp.

Keane, A. H. 1880. On the relations of the Indo-Chinese and Inter-Oceanic races and languages. Journal of the Anthropological Institute 9:254-289.

Li, Paul Jen-Kuei. 1973. Rukai structure. Special Publication no. 64. Nankang, Taipei: Institute of History and Philology, Academia Sinica.

- 1975. Rukai texts. Special Publication no. 64-2. Nankang, Taipei: Institute of History and Philology, Academia Sinica.

Man, E. H. 1889. Dictionary of the Central Nicobarese language. London.

Manley, Timothy M. 1972. Outline of Sre structure Oceanic Linguistics Special Publication 12. Honolulu: University of Hawaii Press.

Maspero, H. 1912. Etudes sur la phonetique historique de la langue annamite. Bulletin de l'Ecôle Française d'Extrême-Orient 12:1-127.

Matson, Dan Mitchell. 1964. A grammatical sketch of Juang, a Munda language. Ph.D. dissertation, University of Wisconsin.

McKaughan, Howard P. 1958. The inflections and syntax of Maranao verbs. Manila: Institute of National Language.

Nacaskul, Karnchana. 1978. The syllabic and morphological structure of Cambodian words. Mon-Khmer Studies 7:190-200. Honolulu: The University Press of Hawaii.

Parkin, Robert. 1991. A guide to Austroasiatic speakers and their languages. Oceanic Linguistics Special Publication no. 23. Hawaii: University of Hawaii Press.

Premsrirat, Suwilai. 1991. Aspects of inter-clausal relations in Khmu. In Austroasiatic languages: Essays in honor of H. L. Shorto, ed. by J. H. C. S. Davidson, pp. 123140. London: School of Oriental and African Studies, University of London.

Pinnow, Heinz-Jurgen. 1966. A comparative study of the verb in Munda languages. In Studies in comparative Austroasiatic linguistics, ed. by Norman A. Zide, pp. 96-193. Indo-Iranian Monograph 5. The Hague: Mouton.

Rabel, Lili. 1961. Khasi, a language of Assam. Louisiana State University Studies, Humanities Series 10. Baton Rouge: Louisiana State University Press.

Rabel-Heymann, Lili. 1977. Gender in Khasi nouns. Mon-Khmer Studies 6:247-271. Hawaii: The University Press of Hawaii.

Radhakrishnan, R. 1970. A preliminary descriptive analysis of Nancowry. Ph.D. dissertation, University of Chicago.

Reid, Lawrence A. 1992. On the development of the aspect systems in some Philippine languages. Oceanic Linguistics 31:65-92.

Ruhlen, Merritt. 1987. A guide to the languages of the world. London: Edward Arnold. 
Sagart, Laurent. 1990. Chinese and Austronesian are genetically related. Paper presented to the 23rd International Conference on Sino-Tibetan Languages and Linguistics, Arlington, Texas.

Schachter, Paul, and Fe T. Otanes. 1972. Tagalog reference grammar. Berkeley: University of California Press.

Schiller, Eric. 1987. Causativity in Southeast Asia. University of California Working Papers in Linguistics 3:201-219.

- 1988. Which way did they grow? (Morphology and the Austro-Tai/(Macro) Austric debate). In Papers from the Chicago Linguistic Society 24th Regional Meeting, pp. 235-246.

Schmidt, Pater Wilhelm. 1906. Die Mon-Khmer-Völker, ein Bindeglied zwischen Völkern Zentralasiens und Austronesiens. Archiv der Anthropologie (Braunschweig) n.s., 5:59-109.

- 1916. Eineges über das Infix $m n$ und dessen stellvertreter $p$ in den austroasiatischen Sprachen. Aufsätze zur Kultur- und Sprachgeschichte, vornehmlich des Orients, Ernst Kuhn zum 70, pp. 457-474. Breslau: Marcus.

Sey, You. 1976. Some old Khmer affixation. Mon-Khmer Studies 5:85-95. Manila: The Summer Institute of Linguistics.

Smith, Kenneth. 1976. Sedang pronouns. Mon-Khmer Studies 5:164-178. Manila: The Summer Institute of Linguistics.

Starosta, Stanley. 1967. Sora syntax: A generative approach to a Munda language. Ph.D. dissertation, University of Wisconsin.

Starosta, Stanley, Andrew K. Pawley, and Lawrence A. Reid. 1981. The evolution of focus in Austronesian. Unpublished typescript. $154 \mathrm{pp}$.

Thomas, David D. 1971. Chrau grammar. Oceanic Linguistics Special Publication no. 7. Honolulu: University of Hawaii Press.

- 1976. A Chrau noun phrase battery. Mon-Khmer Studies 5:135-138. Manila: The Summer Institute of Linguistics.

Thomas, Dorothy M. 1969. Chrau affixes. Linguistic Circle of Saigon Publication no. 4. Mon-Khmer Studies 3:90-107. Saigon: Summer Institute of Linguistics and Linguistic Circle of Saigon.

Thompson, Laurence C. 1984-1985. A Vietnamese reference grammar. Mon-Khmer Studies 13-14. Honolulu: University of Hawaii Press.

Tsuchida, Shigeru. 1976. Reconstruction of Proto-Tsouic phonology. Study of Languages and Cultures of Asia and Africa Monograph Series No. 5. Tokyo: Institute for the Study of the Languages and Cultures of Asia and Africa.

Watson, Saundra K. 1966. Verbal affixation in Pacoh. Mon-Khmer Studies 2:15-30. Saigon: The Linguistic Circle of Saigon and The Summer Institute of Linguistics.

Wolff, John U. 1972. A dictionary of Cebuano Visayan. Philippine Journal of Linguistics, Special Monograph no. 4. Manila: Linguistic Society of the Philippines.

- 1973. Verbal inflection in Proto-Austronesian. In Essays in honor of Cecilio Lopez, ed. by Andrew B. Gonzalez, F. S. C., pp. 71-91. Philippine Journal of Linguistics Special Monograph, Manila.

Wurm, S. A., and Shiro Hattori, eds. 1981. Language atlas of the Pacific area. Canberra: Australian Academy of the Humanities in collaboration with the Japan Academy. 
http://www.jstor.org

\title{
LINKED CITATIONS \\ - Page 1 of 1 -
}

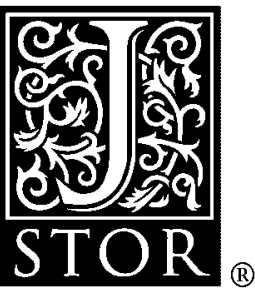

You have printed the following article:

Morphological Evidence for Austric

Lawrence A. Reid

Oceanic Linguistics, Vol. 33, No. 2. (Dec., 1994), pp. 323-344.

Stable URL:

http://links.jstor.org/sici?sici=0029-8115\%28199412\%2933\%3A2\%3C323\%3AMEFA\%3E2.0.CO\%3B2-Z

This article references the following linked citations. If you are trying to access articles from an off-campus location, you may be required to first logon via your library web site to access JSTOR. Please visit your library's website or contact a librarian to learn about options for remote access to JSTOR.

\section{References}

On the Relations of the Indo-Chinese and Inter-Oceanic Races and Languages.

\author{
A. H. Keane \\ The Journal of the Anthropological Institute of Great Britain and Ireland, Vol. 9. (1880), pp. \\ 254-289. \\ Stable URL: \\ http://links.jstor.org/sici?sici=0959-5295\%281880\%299\%3C254\%3AOTROTI\%3E2.0.CO\%3B2-9
}

\section{On the Development of the Aspect System in Some Philippine Languages}

Lawrence A. Reid

Oceanic Linguistics, Vol. 31, No. 1. (Summer, 1992), pp. 65-91.

Stable URL:

http://links.jstor.org/sici?sici=0029-8115\%28199222\%2931\%3A1\%3C65\%3AOTDOTA\%3E2.0.CO\%3B2-J 